\title{
Six Sigma practice for quality improvement - A case study of Indian auto ancillary unit
}

\author{
Dr. Rajeshkumar U. Sambhe \\ Department of Mechanical Engineering Jawaharlal Darda Institute of Engg. \& Technology M.I.D.C. Area, \\ Lohara, Yavatmal-445001 Maharashtra, India.
}

\begin{abstract}
Indian automotive ancillary units are one of the swift growing within the small and mid-sized group of industries which are influential contributors to the complete production of auto components. With the ascent in interrogation of growing customers and presuming for resplendent quality of their product, some of giant Indian organizations are inspiring their suppliers to employ Six Sigma in order to improve the quality of their process and products for embellishing competitive advantage. This paper focus on a case of provoked mid-sized auto ancillary unit consisting of 350-400 employee and employed Six Sigma (SS) methodologies to elevate towards the dream of SS quality level. The methodology is executed on one of product assembly for trimming down defects level which are critical to customers and its implementation has had a significant financial hit on the bottom-line of the enterprise.
\end{abstract}

Keywords: Indian SMEs, Six Sigma, DMAIC, Critical to Quality, Successful implementation

\section{Introduction}

As per automotive survey, the Indian automobile industry is the largest three wheeler market in the world, 2nd largest two wheeler market in the world, 4th largest passenger vehicle market in Asia, 4th largest tractor market in the world and 5th largest commercial vehicle market in the world (A report by KPMG for IBEF, 2006). India is emerging as one of the most attractive automotive markets in the globe, and is poised to become a key sourcing base for auto components. Many enterprises think to shift in the higher tier but no production enterprise can expect persistence success without company detainment on product quality. The productive capacity in auto ancillary enterprises in India is in essence excelling than contrasting sectors and it has an elephantine potency to promote improvement, which in turn will extract the effectiveness of absolute manufacturing sector. Hence it becomes imperative to ascertain ingredients that frame manufacturing in India to deliver right quality and perk up the competitiveness. The attainment of large company's quality is essentially relying on the delivery of goods with elevated quality and honest services from suppliers, which are most likely to be small medium scale enterprises (SMEs) and are the vital spark of modern economies. SMEs should remain combative and compose high quality yield is of importance notability at the small and mid-sized but also for giant enterprises. In case, destitution of commodity quality in SMEs would impinge upon and affect the competence of the larger corporations.

As such, innumerable new techniques have been developed to improve quality, reduce cost and improve responsiveness. Many more quality practices and frameworks have been developed, built or strategized to escalate the competitiveness of businesses in the modern world. Statistical Process Control (SPC), ISO 9000, KAIZEN, Total Quality Management (TQM), Benchmarking, Theory of constraints, Business Excellence models, and other improvement programs have been adopted and implemented by various enterprises. However, Six Sigma (SS) is a quality improvement methodology developed by Motorola. It was proclaimed as a new approach to improving quality through statistical measurements and benchmarking. Despite the apparent popularity of Six Sigma, very little is known about the extent to which Six Sigma has actually been adopted by various firms in the India, specifically SMEs, the patterns of adoption across industrial sectors and occupational groups and the factors that differentiate firms that heavily adopt Six Sigma from those that do not. According to IDC report (2008), Department of Scientific \& Industrial Research (DSIR), small and medium enterprises can be defined as "Small enterprises are those companies who have an investment in plant and machinery of up to INR 5 Crores. Medium enterprises are the ones who have an investment between INR 5 Crores to INR 10 Crores in plant and machinery. Companies having a turnover of up to INR 50 Crores were considered as small company and companies with turnover in the range of Rs. 50 to 250 Crores were considered as medium companies". As there are abundant benefits from Six Sigma implementation but there are many more issues in regards to small medium scale enterprises. So, it is necessity to rivet on these problems under consideration before the implementation and deployment of Six Sigma strategy. The availability of human capital is the crucial challenge for SMEs. The other factors as to the constraints are technical coherence, financial attributes and inadequate experience also had been an issue of concern for SMEs. Expensive consultation is major barrier in concern of SMEs and so designing training methodology which can afford to SMEs as rigorous need. The 
giant auto sectoral Indian organizations like TATA motors initiated encouraging their supplier to apply the wellascertain SS as a quality management practice.

\section{COMPARING SIX SIGMA WITH QUALITY MANAGEMENT PRACTICES}

In general, quality management approaches can be classified into two broad categories, industryspecific QM and non-industry-specific QM. For example, some QM program such as ISO 14000, AS9100, QS 9000, and TL 9000 are industry specific and others, including Lean management, Six Sigma, Total Quality Management, and ISO 9000:2000, are company-wide quality management programs. Commonly observed benefits of ISO are better documentation, quality awareness and help to take more market advantage. Total quality management is a never-ending process to satisfy both the internal and the external customers and the core ideas presented by Deming, Juran, Crosby, and Ishikawa are the key elements of TQM. Lean Management mainly focuses on Process flow (Bell, R., 2011). SS seeks to improve the quality of process (Pfeifer, T. et. al, 2004) outputs by identifying and removing the causes of defects (errors) and minimizing variability in manufacturing and business processes (Does, R. et. al, 2002). But Six Sigma is all about process performance and TQM focuses on all activities.

\section{FACETS OF SIX SIGMA IMPLEMENTATION IN SMEs}

The motivation behind Six Sigma is to reduce the cost that arises from poor quality. Quality related costs have been measured to be as much as $40 \%$ of sales in some organizations. These costs, known as the Costs of Poor Quality (COPQ), can occur in many different ways ranging from scrapping of work in process, customer returns after the products are sold and even retyping letters (Berghe W., 1997). The limited resources of a small or medium size organization can pose difficulties for the implementation of Six Sigma such as employee education, flow of information and practical experimentation (Patel, D. 2004).The common norm that surrounds the hierarchy of necessary green, yellow and black belt training can be misleading for small organizations. A successful implementation in a small organization does not require all levels of training. Gnibus and Krull (2003) noticed in their testing that training to the green belt level yielded excellent results for the organization in their test. The training can be costly and time consuming and only training to a green belt level can prove successful without the excessive costs involved with other levels of training. There are two options regarding the training for Six Sigma (Pandey, A. 2007).

An organization can develop an in-house education structure or can hire an outside firm. Breyfogle et al. states that an in-house training program is probably not the best idea because it can take years to develop the needed resources to have a successful program. If an outside firm is hired they will commonly train a smaller group of people and allow those people to use the training material to train others in the organization. This process will be a faster and more effective structure due to the experience the trainers have with Six Sigma. It may look more expensive in the beginning, but the cost of employees developing a program that is not effective would cost a great deal more. A small organization will not likely have the resources to develop any kind of effective Six Sigma training and will have the most success by hiring a competent firm to educate a handful of individuals to manage projects within the company. Thomas et al. showed success in a small organization with only one individual trained to the black belt level. Gnibus and Krull observed successful results with a handful of individuals trained to the green belt level. These are two different approaches that both yielded success. This shows that the implementation's success does not depend on the level of the training, but on the ability of individuals to teach, connect, communicate, learn and understand the scope of the education, not only applying it to problems faced but extending it to new types of unforeseen problems. A small organization can be successful at implementing the Six Sigma plan using these principles.

Patel D. (2004) also bring into focus that the level of training does not determine the degree of success the organization will have. If the organization is willing to adopt the methodologies and work with a limited amount of training, they will be able to successfully apply it to the issues that will arise in the organization even though they have not trained to the extent of much larger organizations. Specific case illustrations are which are discussing successful application of Six Sigma at small and medium sized Indian industries (Desai, 2008, 2006). But an exhaustive empirical study of mid-sized automotive sectors of Indian industries with Six Sigma is unapproachable in research publications.

\section{SIX SIGMA IMPLEMENTATION- CASE STUDY}

SIX SIGMA

Kumi et. al., (2006) defined Six Sigma is a statistical measure of the performance of a process or product. It is used as a quality control mechanism, which seeks to reduce defects or variations in a process to 3.4 per million opportunities thereby optimizing output and increasing customer satisfaction. This is as close to perfection as possible as 99.99966 per cent of the time it would be perfect. In addition to Six Sigma is uniquely 
driven by close understanding of customer needs, disciplined use of facts, data, and statistical analysis, and diligent attention to managing, improving, and reinventing business processes (Pande, P., et. al. 2000)

\subsection{THE DMAIC SIX SIGMA METHODOLOGY}

The Six Sigma is not merely a quality improvement strategy in theory, as it features a well defined methodical approach of application in DMAIC and DMADV which can be used to improve the quality of production. At the core of DMAIC, the framework is a formalized improvement strategy with the following five facets i.e. define, measure, analyze, improve and control (DMAIC). The methodology is acknowledged with different facets (Fig. 1) which is portrayed in I, II, III, IV and V and accomplished for this case.

\section{Define Phase}

\section{Development of a Project Charter}

The define facet of Six Sigma adjudicates the objectives and the goal of the project. This phase also pile up evidences on processes and particularize the yield to internal and end customers.

\section{Opportunity statement}

- Reduction in PPM Level at final assembly line which will reduce in rework, field failure, increase the productivity and thus improve customer satisfaction.

- As a result of high PPM Level, customer satisfaction is low.

\section{Goal Statement}

- Reductions in internal PPM from 18909 PPM to 2500 PPM for Lighting stalk assembly.

\section{Critical to Quality}

Table 1 shows the constituent within a process that has a vital ascendancy on the process quality and customary the quality of a crucial process, or need more attention in Six Sigma project.

Table 1 Critical to Quality

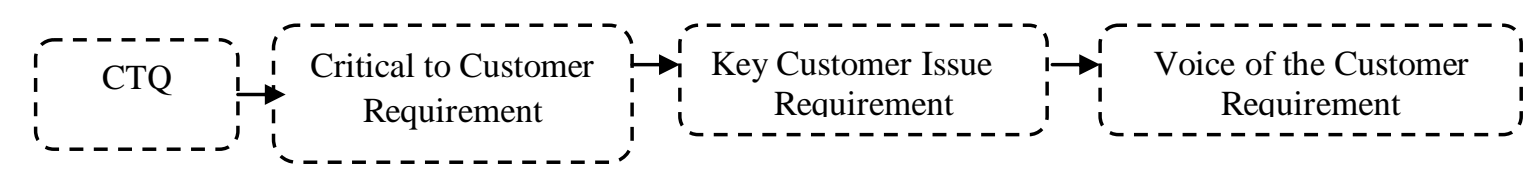

\begin{tabular}{|c|c|c|c|}
\hline $\begin{array}{l}\text { PPM } \\
\text { level }\end{array}$ & $\begin{array}{l}\text { PPM } \\
\text { level less } \\
\text { than } 2500 \\
\text { (For total } \\
\text { defects ) }\end{array}$ & $\begin{array}{l}\text { 1. No noise / Low noise level from steering } \\
\text { wheel } \\
\text { 2. Wiper system should function whenever } \\
\text { operates the Combi switch. } \\
\text { 3. Combi- switch side indicator function } \\
\text { should not fail. } \\
\text { 4. Horn should function whenever SW } \\
\text { operates. }\end{array}$ & $\begin{array}{l}\text { 1. Noise from steering wheel } \\
\text { while turning of vehicle. } \\
\text { 2. Wiper is not working in flick } \\
\text { wiper mode. } \\
\text { 3. Side indicator not working. } \\
\text { 4. Horn is not blowing }\end{array}$ \\
\hline
\end{tabular}

SIPOC Diagram

Table 2 threads the transfiguration operation of inputs from suppliers to output for customers. It focuses on the stage-wise apprehension of the process and their allegory to each other.

Table 2 SIPOC Diagram

\begin{tabular}{|c|c|c|c|c|}
\hline Supplier & Input & Process & Output & Customer \\
\hline \multirow[t]{3}{*}{$\begin{array}{c}\text { Component } \\
\text { stores }\end{array}$} & $\begin{array}{l}\text { Lighting stalk } \\
\text { assembly }\end{array}$ & $\begin{array}{l}\text { Combination } \\
\text { Switch assembly }\end{array}$ & $\begin{array}{l}\text { Assembled } \\
\text { Switch }\end{array}$ & $\begin{array}{c}\text { Inspection and } \\
\text { External Customer M1 }\end{array}$ \\
\hline & Wiper stalk assembly & & & \\
\hline & $\begin{array}{l}\text { Central housing } \\
\text { assembly }\end{array}$ & & & \\
\hline
\end{tabular}

The SIPOC is generated for each subassembly and then input indicators for each process is noted as in Table 3 (Complete list of input indicators is to be listed as in Table 3) 


\begin{tabular}{|l|l|}
\hline Input & Table 3 Input indicators \\
\hline Contact Pin & Input Indicators \\
\hline & Material specification \\
\hline & Dimensions \\
\hline Clating & Pock dimensions \\
\hline & Flash \\
\hline & Pawi fitment dimensions \\
\hline & Profile \\
\hline & Pivoting Pin Diameter \\
\hline & Siot Dimensions for Action slide movement \\
\hline
\end{tabular}

Table 4 lists out most basic steps of process where the major steps on the top of board in order that they occur in process. Under each major step, there is need of listing the different sub-steps that make up the element of the process.

Table 4 Process mapping through Top-Down Charting

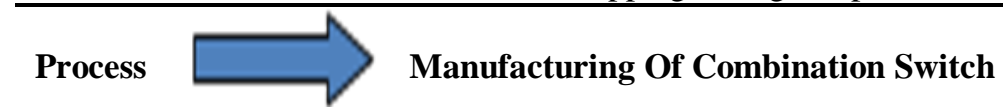

\begin{tabular}{|c|c|c|c|c|}
\hline $\begin{array}{l}\text { Sub } \\
\text { processes }\end{array}$ & $\begin{array}{l}\text { Lighting stalk } \\
\text { assembly }\end{array}$ & $\begin{array}{l}\text { Wiper stalk } \\
\text { assembly }\end{array}$ & $\begin{array}{l}\text { Central housing } \\
\text { assembly }\end{array}$ & $\begin{array}{l}\text { Mounting of } \\
\text { subassembly }\end{array}$ \\
\hline \multirow[t]{5}{*}{ Activities } & $\begin{array}{l}\text { LCS base soldering } \\
\text { and } \\
\text { inspection }\end{array}$ & $\begin{array}{lr}\text { Wiper } & \text { base } \\
\text { soldering and } & \text { and } \\
\text { visual inspection }\end{array}$ & 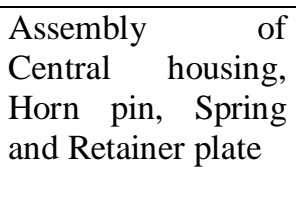 & \multirow{5}{*}{$\begin{array}{l}\text { Mounting of } \\
\text { lighting stalk } \\
\text { sub assembly, } \\
\text { wiper stalk } \\
\text { subassembly, } \\
\text { central housing } \\
\text { assembly }\end{array}$} \\
\hline & $\begin{array}{l}\text { Screwing of lever, } \\
\text { Spacer, and LCS } \\
\text { fret base }\end{array}$ & $\begin{array}{l}\text { Wiper assembly } \\
\text { riveting and visual } \\
\text { inspection }\end{array}$ & Screwing & \\
\hline & CPC assembly & $\begin{array}{l}\text { Riveting of } 6 \\
\text { contact pins }\end{array}$ & $\begin{array}{l}\text { Assembly of clamp } \\
\text { plate, Nut, Spring }\end{array}$ & \\
\hline & $\begin{array}{l}\text { CPC assembly with } \\
\text { lever }\end{array}$ & $\begin{array}{l}\text { Riveting of contact } \\
\text { blade, contact pins } \\
\text { wash feed link and } \\
\text { link blade }\end{array}$ & $\begin{array}{l}\text { Mounting of striker } \\
\text { bush with } \\
\begin{array}{l}\text { application } \\
\text { grease }\end{array}\end{array}$ & \\
\hline & $\begin{array}{l}\text { Screwing of cap } \\
\text { assembly with CPC } \\
\text { assembly }\end{array}$ & Visual inspection & Date Stamping & \\
\hline
\end{tabular}

Table 5 Process Indicators for Lighting Stalk

\begin{tabular}{l|l}
\hline Head Off /Blink & Printing Defective \\
\hline Park / Head Circuit Interchanged & Right engagement return \\
\hline LCS Snap Defective & Right lane change off \\
\hline D.I. Snap & Left lane change off \\
\hline Head OFF & Rivet bend \\
\hline Flash Operation Noisy (H/D) & Check date stamping. \\
\hline L- Side Indicator OFF & \\
\hline
\end{tabular}

\section{Measure Phase}

This phase forms the measurement systems for the inputs and outputs of the selected project with major focus on lighting stalk assembly. It also ensure that way of aggregating data as well accumulated data is right data from right place. If data accruement manner is wrong then it will provide inaccurate inferences in the phases underneath. Therefore, achieving success in the measure phase is vital. For SS project, an operational 
definition focuses on meticulous definition of a measure while collecting every type of data and is well-defined. The data accumulation will be senseless if the definition has not been delimitated in time. So, operational definitions should be eventuated and verified before the data picking up commences.

Then data collection for complete 30 days of production processes was measured as per operational definition for each defect from process indicators for each sub-assembly was analyzed but this paper specifically focuses on SS employment on lighting stalk assembly. The PPM level of each sub assemblies is shown below:

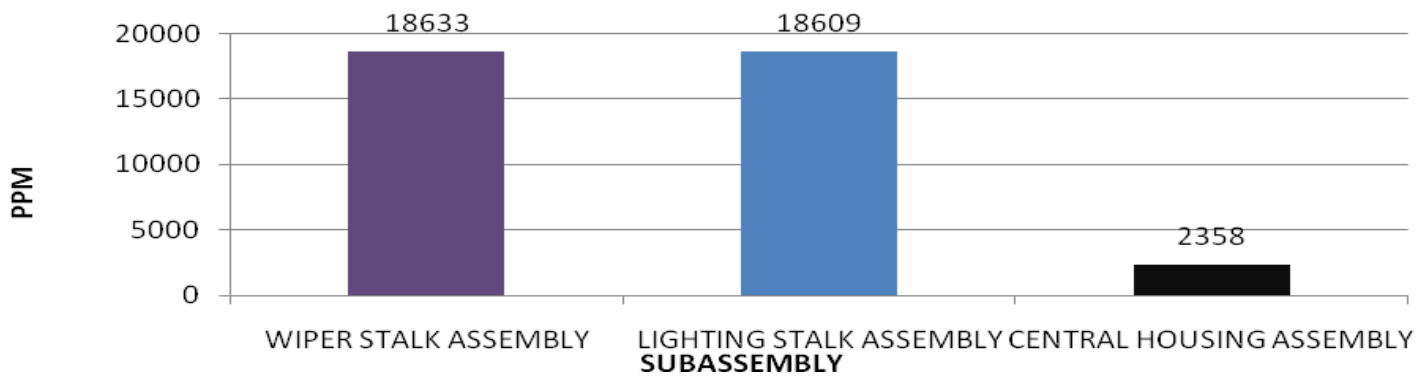

Figure 2 First level Pareto showing PPM level for each subassembly

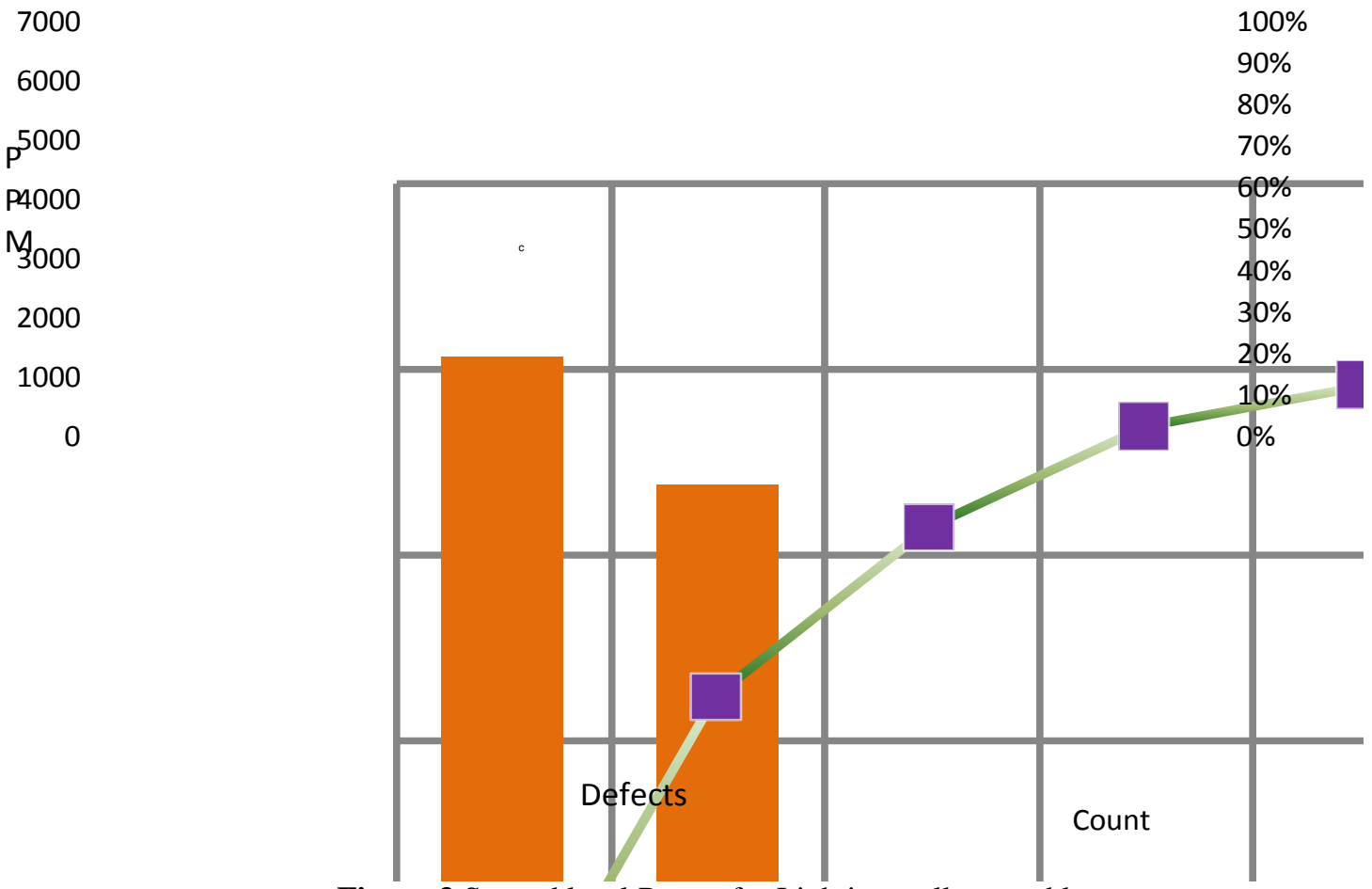

Figure 3 Second level Pareto for Lighting stalk assembly

Measuring Process Indicators:

It is necessary to find which inputs affect outputs (CTQ's) most. The following observation shows the measurement of data with regards to lighting stalk assembly.

Table 6 Notations for Process indicator

\begin{tabular}{lcc}
\hline Process Indicators & Notation & Measurement \\
Parking OFF/ Blink & y1 & Ref. Figure 4 \\
Printing Defective & y2 & Ref. Figure 5 \\
LCS Snap defective & y3 & Ref. Figure 6 \\
D.I. Snap & y4 & Ref. Figure 7 \\
Head Off/ Blink & y5 & Ref. Figure 8 \\
Right Lane change Off & y6 & Ref. Figure 9 \\
\hline
\end{tabular}


Six Sigma practice for process improvement - A case study of medium scale auto ancillary unit

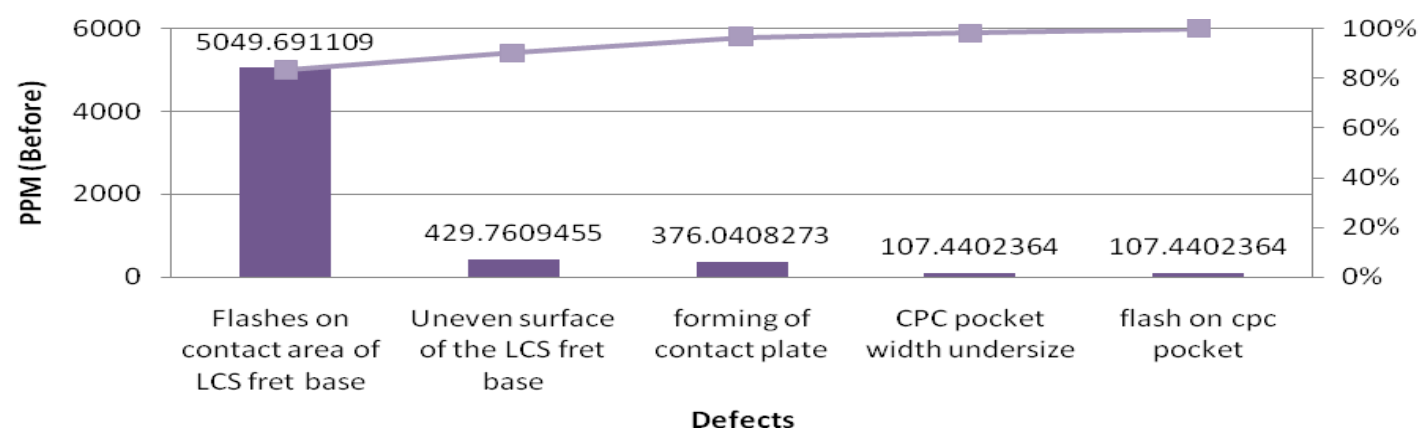

Figure 4 Measurement of Parking Off/ Blink defectives (y1)

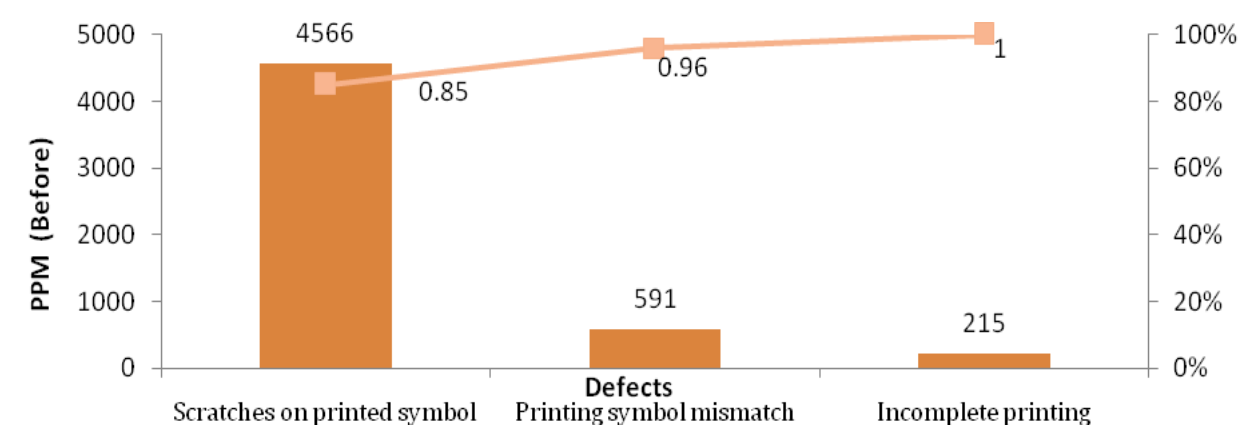

Figure 5 Measurement of printing defectives (y2)

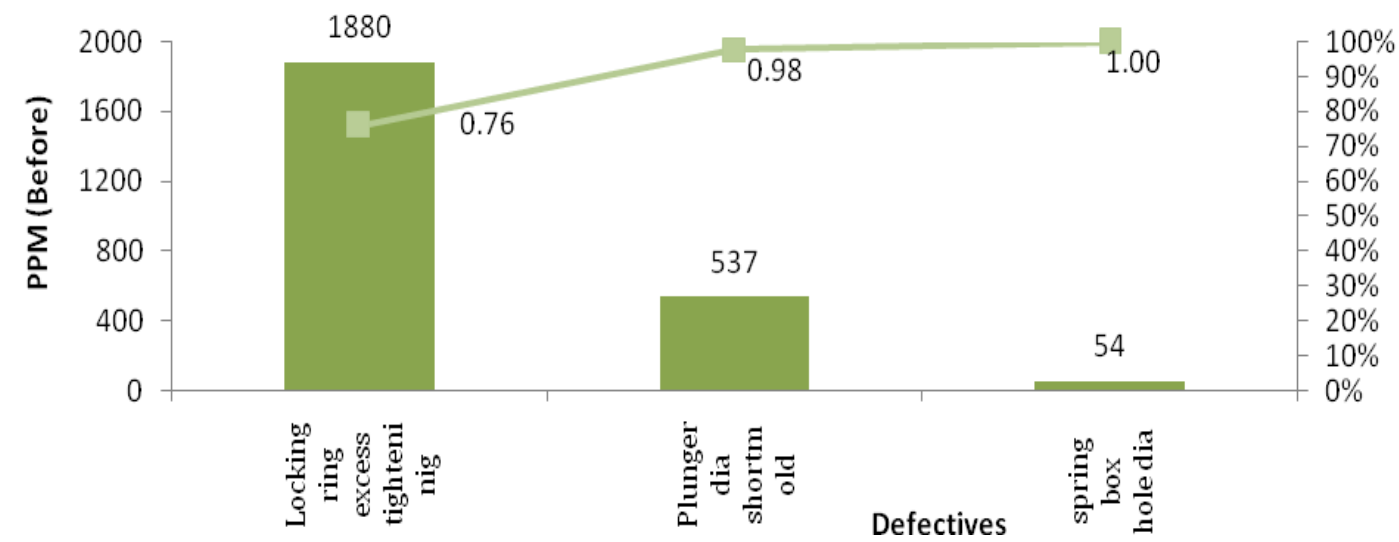

Figure 6 Measurement of LCS Snap defectives (y3)

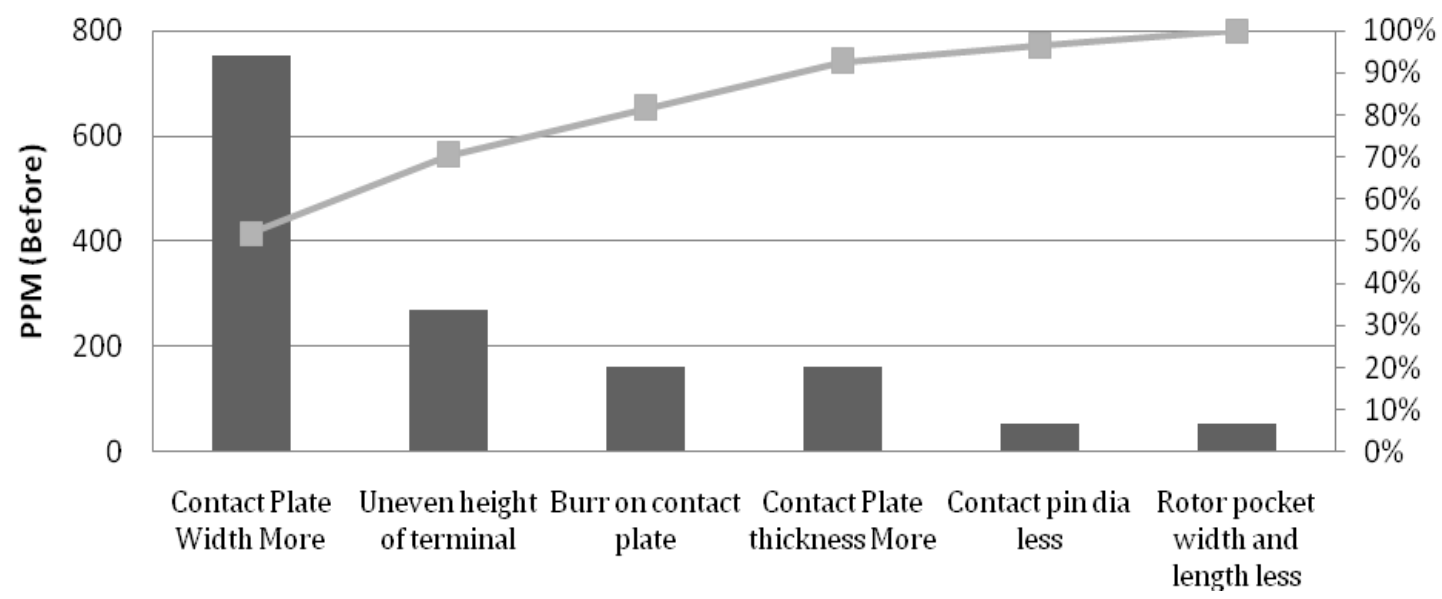

Figure 7 Measurement of DI Snap defectives (y4) 


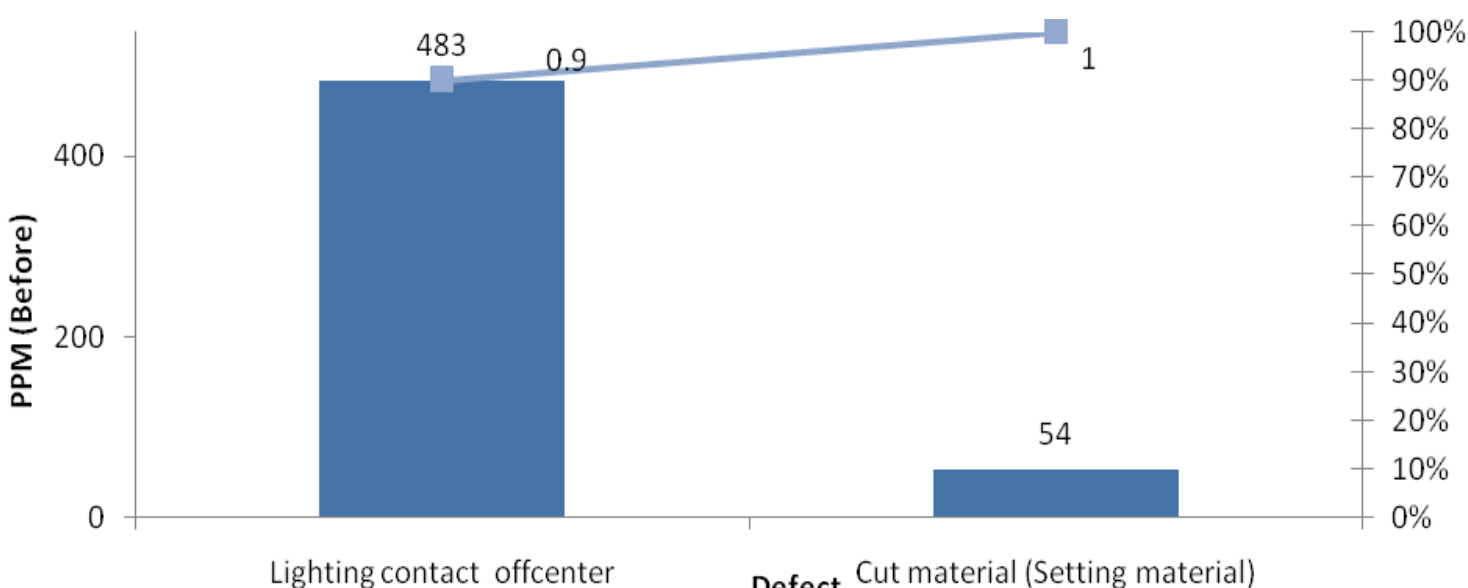

Figure 8 Measurement of Head Off/ Blink defectives (y5)

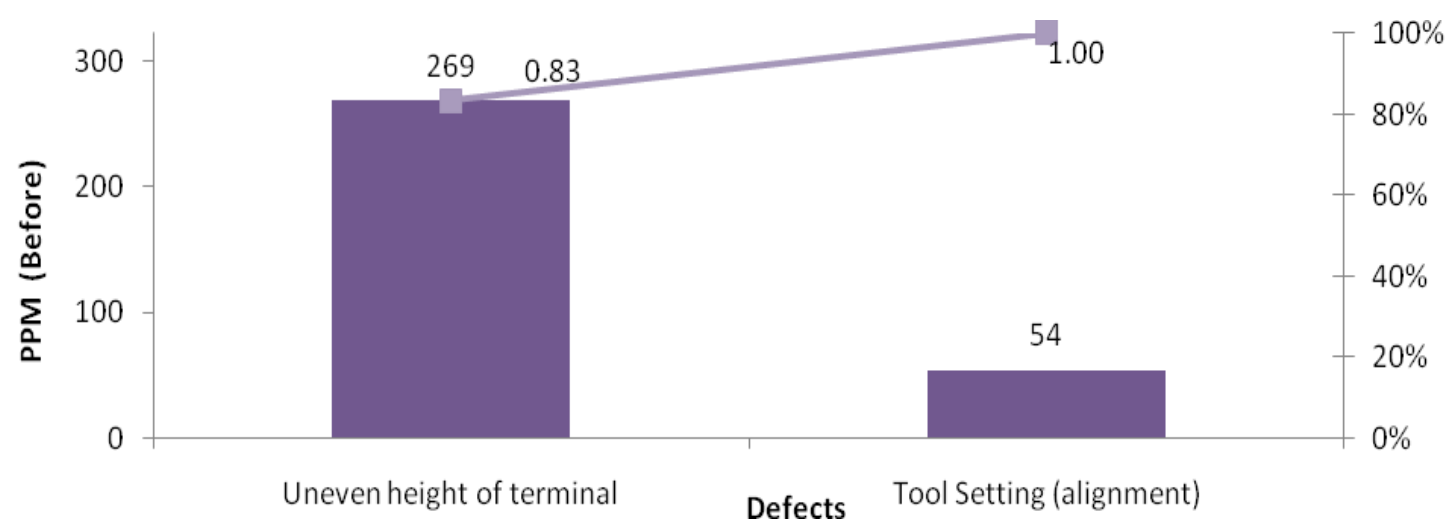

Figure 9 Measurement of right lane change off effectives (y6)

Preliminary Failure Mode \& Effect Analysis (FMEA) is also employed in this measure phase which supports to establish the identity and accomplish apparent predicament in order to curtail defects and redeem costs as soon as possible.

\section{Outcome from Measure Phase:}

Benchmark period is assigned for PPM level of rejection at customer end and internal assembly. In project scope start should be from receipt of raw material / component from own organisation. Internal failure cost should co-relate with the 2500 PPM target. In SIPOC, the list of component Part No. should be given in a part description. In process walk through should be in details like include the observation on housekeeping, assembly layout, material flow, visual control and work instructions. Special process on the shop floor should be identified separately. Additional Operating resources for data collection are required and will be provided.

\section{Analyze Phase}

Analyze phase appraises and bring down the variables using box plot, descriptive statistics analysis, hypothesis testing and assesses the most critical measures for process improvement. So, the measurements piled up from the measure phase are examined so that hypothesis about the root causes of variations in the measurements can be generated and the hypothesis subsequently validated. It is at this stage that practical dilemma are turned into statistical problems and analyzed as statistical problems. The relevant outputs and all the potential inputs (x) that might impact each output are connected to each other. So, the vital inputs $(\mathrm{x})$ are appraised using graphical analysis as shown below:

\section{Cause and Effect Diagram:}

In this project, especially a team brainstorming analysis tool is cause and effect diagram also called a fishbone diagram because the diagram plots contributing factors along parallel diagonal lines which each join a central horizontal time-line (like the back-bone) which culminates at one end with the main issue or question. 
Table 7 Cause-Effect Matrix:

\begin{tabular}{|c|c|c|c|c|c|}
\hline & & $\begin{array}{l}\text { Out } \\
\text { put } \\
\# 2 \\
10\end{array}$ & $\begin{array}{c}\text { Outp } \\
\text { ut \#2 } \\
10\end{array}$ & $\begin{array}{l}\text { Output } \\
\text { \#3 } \\
10\end{array}$ & $\begin{array}{c}\quad<<<\text { Output } \\
\text { Indicators } \\
\text { e } 2<<<<<<\text { Import } \\
\text { ance }(1-10 \text { scale })\end{array}$ \\
\hline Input' & <<Input/Process Indicators $<<$ & \multicolumn{3}{|c|}{$\begin{array}{l}\text { Correlation of Input to } \\
\text { Output }\end{array}$} & $\begin{array}{c}\ll<< \\
\text { Total }<<<<< \\
\end{array}$ \\
\hline \multirow[t]{2}{*}{ Contact Pin } & $\begin{array}{l}\text { Material specification } \\
\text { Hardness }\end{array}$ & $\begin{array}{l}0 \\
3\end{array}$ & $\begin{array}{l}0 \\
0\end{array}$ & $\begin{array}{l}0 \\
0\end{array}$ & $\begin{array}{l}0 \\
30\end{array}$ \\
\hline & $\begin{array}{l}\text { Dimensions } \\
\text { Plating }\end{array}$ & $\begin{array}{l}1 \\
0\end{array}$ & $\begin{array}{l}0 \\
0\end{array}$ & $\begin{array}{l}0 \\
0\end{array}$ & $\begin{array}{l}10 \\
0\end{array}$ \\
\hline \multirow[t]{5}{*}{ Cover } & Lock dimensions & 0 & 0 & 0 & 0 \\
\hline & $\begin{array}{l}\text { Flash } \\
\text { Pawl fitment dimensions }\end{array}$ & $\begin{array}{l}9 \\
9\end{array}$ & $\begin{array}{l}\mathbf{0} \\
\mathbf{0}\end{array}$ & $\begin{array}{l}\mathbf{0} \\
\mathbf{0}\end{array}$ & $\begin{array}{l}90 \\
90\end{array}$ \\
\hline & Profile & 0 & 0 & 0 & 0 \\
\hline & Pivoting Pin Diameter & 0 & 0 & 0 & 0 \\
\hline & $\begin{array}{l}\text { Slot Dimensions for Action slide } \\
\text { movement }\end{array}$ & 3 & 0 & 0 & 30 \\
\hline \multirow[t]{6}{*}{ Base } & $\begin{array}{l}\text { Hole Diameters for contact pin } \\
\text { assembly }\end{array}$ & 3 & 0 & 0 & 30 \\
\hline & Pivoting Hole Diameter & 0 & 0 & 0 & 0 \\
\hline & Slot Dimensions for contact slide & 1 & 0 & 0 & 10 \\
\hline & Flash & 1 & 0 & 0 & 10 \\
\hline & counter depth on hole & 3 & 0 & 0 & 30 \\
\hline & Slot width and slot for link blade & 3 & 0 & 0 & 30 \\
\hline \multirow[t]{6}{*}{ Lever } & $\begin{array}{l}\text { Diameter of pivoting where the } \\
\text { rotor fitment take place }\end{array}$ & 1 & 0 & 0 & 10 \\
\hline & Fork Hole diameter & 0 & 0 & 0 & 0 \\
\hline & Hole diameter for screwing & 1 & 0 & 0 & 10 \\
\hline & Flash & 1 & 0 & 0 & 10 \\
\hline & Printing quality & 1 & 0 & 0 & 10 \\
\hline & Material grade & 0 & 0 & 0 & 0 \\
\hline \multirow[t]{6}{*}{ LCS Base } & Flatness & 9 & $\mathbf{0}$ & $\mathbf{0}$ & 90 \\
\hline & Flash & 9 & $\mathbf{0}$ & $\mathbf{0}$ & 90 \\
\hline & Hole diameter for screw head & 1 & 0 & 0 & 10 \\
\hline & Stem height & 1 & 0 & 0 & 10 \\
\hline & counter depth on hole & 3 & 0 & 0 & 30 \\
\hline & Slot width and slot for link blade & 3 & 0 & 0 & 30 \\
\hline \multirow[t]{4}{*}{ Pawl } & Thickness & 3 & 0 & 0 & 30 \\
\hline & Flash & 3 & 0 & 0 & 30 \\
\hline & Total length & 0 & 0 & 0 & 0 \\
\hline & Peg Height & 0 & 0 & 0 & 0 \\
\hline \multirow[t]{4}{*}{ Action Slide } & Flash & 3 & 0 & 0 & 30 \\
\hline & Thickness & 3 & 0 & 0 & 30 \\
\hline & Length & 0 & 0 & 0 & 0 \\
\hline & Triangular Profile & 0 & 0 & 0 & 0 \\
\hline \multirow{5}{*}{$\begin{array}{l}\text { Lighting } \\
\text { contact }\end{array}$} & Locking Height & 9 & $\mathbf{0}$ & $\mathbf{0}$ & 90 \\
\hline & Thickness & 3 & 0 & 0 & 30 \\
\hline & Burr & 3 & 0 & 0 & 30 \\
\hline & Locking dimple Position in center & 1 & 0 & 0 & 10 \\
\hline & Contact area flatness & 1 & 0 & 0 & 10 \\
\hline
\end{tabular}


Six Sigma practice for process improvement - A case study of medium scale auto ancillary unit

Table 8 Notations for Potential Inputs

\begin{tabular}{|l|c|c|}
\hline Potential input $(\mathrm{x})$ & Notation & Measurement \\
\hline Flashes on contact area of LCS fret base & $\mathrm{x} 1$ & Shown in Fig. 11 \\
\hline Locking ring excess tightening & $\mathrm{x} 2$ & Shown in Fig. 12 \\
\hline Contact plate width more & $\mathrm{x} 3$ & Shown in Fig. 13 \\
\hline Scratches on printed Symbol & $\mathrm{x} 4$ & Shown in Fig. 14 \\
\hline Lighting contact off center & $\mathrm{x} 5$ & Shown in Fig. 15 \\
\hline Uneven height of terminal & $\mathrm{x} 6$ & Shown in Fig. 16 \\
\hline
\end{tabular}

\begin{tabular}{|c|c|}
\hline \multicolumn{2}{|c|}{$\begin{array}{l}\text { Descriptive statistics Of Flashes on contact area of } \\
\text { LCS Fret Base (x1) }\end{array}$} \\
\hline & $\begin{array}{l}\text { PPM( Flashes On contact } \\
\text { area }(\mathrm{x} 1)\end{array}$ \\
\hline Count & 30 \\
\hline Mean & 5243.3 \\
\hline Standard Deviation & 3145.6 \\
\hline Range & 15949 \\
\hline Minimum & 1000 \\
\hline 25th Percentile (Q1) & 3333.3 \\
\hline 50th Percentile (Median) & 4766.7 \\
\hline 75th Percentile (Q3) & 6666.7 \\
\hline Maximum & 16949 \\
\hline $95.0 \% \mathrm{Cl}$ Mean & 4068.735 to 6417.913 \\
\hline $95.0 \%$ CI Sigma & 2505.181 to 4228.687 \\
\hline $\begin{array}{l}\text { Anderson-Darling } \\
\text { Normality Test }\end{array}$ & $\begin{array}{l}\text { A-Squared }=1.204421 ; \mathrm{P}- \\
\text { value }=0.0032\end{array}$ \\
\hline
\end{tabular}

Figure 11 Descriptive statistics of flashes on contact area of LCS fret base (x1)

\begin{tabular}{|c|c|}
\hline \multicolumn{2}{|c|}{$\begin{array}{l}\text { Descriptive statistics for locking ring excess } \\
\text { tightening }(x 2)\end{array}$} \\
\hline & $\begin{array}{c}\text { PPM Locking ring Excess } \\
\text { tightening }\end{array}$ \\
\hline Count & 30 \\
\hline Mean & 2245.7 \\
\hline Standard Deviation & 3577.0 \\
\hline Range & 15000 \\
\hline Minimum & 0 \\
\hline 25th Percentile (Q1) & 0 \\
\hline 50th Percentile (Median) & 0 \\
\hline 75th Percentile (Q3) & 3611.1 \\
\hline Maximum & 15000 \\
\hline $95.0 \% \mathrm{Cl}$ Mean & 910.052 to 3581.415 \\
\hline $95.0 \% \mathrm{Cl}$ Sigma & 2848.763 to 4808.644 \\
\hline $\begin{array}{l}\text { Anderson-Darling Normality } \\
\text { Test }\end{array}$ & $\begin{array}{l}\text { A-Squared }= \\
3.495375 ; P \text {-value }= \\
0.0000\end{array}$ \\
\hline
\end{tabular}


Figure 12 Descriptive statistics of locking ring excess tightening (x2)

\begin{tabular}{|c|c|}
\hline \multicolumn{2}{|c|}{ Descriptive Statistics For Contact Plate Width More (x3) } \\
\hline & PPM Contact Plate width More \\
\hline Count & 30 \\
\hline Mean & 722.21 \\
\hline Standard Deviation & 1245.9 \\
\hline Range & 4615.4 \\
\hline Minimum & 0 \\
\hline 25th Percentile (Q1) & 0 \\
\hline $\begin{array}{l}\text { 50th Percentile } \\
\text { (Median) }\end{array}$ & 0 \\
\hline 75th Percentile (Q3) & 1570.5 \\
\hline Maximum & 4615.4 \\
\hline $95.0 \% \mathrm{Cl}$ Mean & 257.0003 to 1187.426 \\
\hline $95.0 \% \mathrm{Cl}$ Sigma & 992.2131 to 1674.832 \\
\hline $\begin{array}{l}\text { Anderson-Darling } \\
\text { Normalitv Tect }\end{array}$ & $\begin{array}{l}\text { A-Squared }=4.838974 ; \text { P-value }= \\
\cap \cap \cap \cap \cap\end{array}$ \\
\hline
\end{tabular}

Figure 13 Descriptive statistics for contact plate width more (x3)

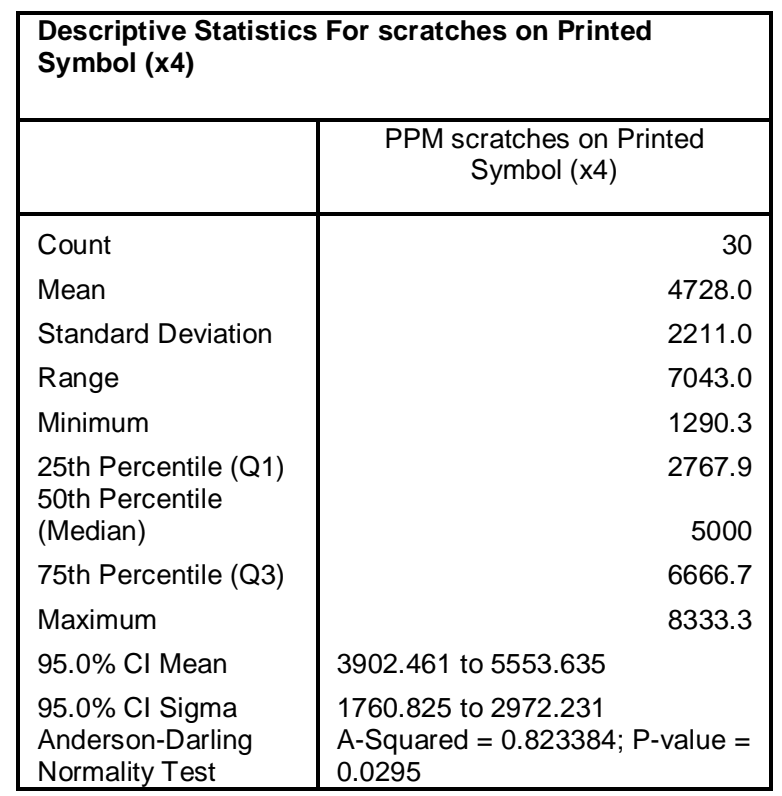

Figure 14 Descriptive statistics for scratches on printed Symbol (x4) 


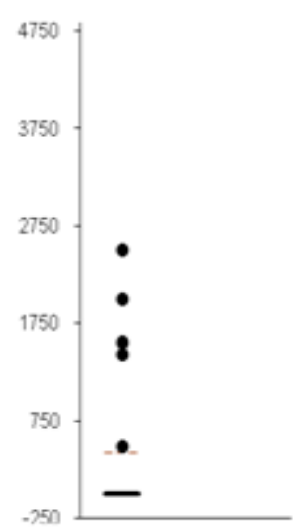

\begin{tabular}{|c|c|}
\hline \multicolumn{2}{|c|}{$\begin{array}{l}\text { Descriptive Statistics For Lighting Contact Off Center } \\
\text { (x5) }\end{array}$} \\
\hline & $\begin{array}{l}\text { PPM Lighting contact off } \\
\text { center }(x 9)\end{array}$ \\
\hline Count & 31 \\
\hline Mean & 417.76 \\
\hline Standard Deviation & 1072.1 \\
\hline Range & 5000 \\
\hline Minimum & 0 \\
\hline 25th Perc entile (Q1) & 0 \\
\hline 50th Percentile (Median) & c \\
\hline 75th Percentile (Q3) & a \\
\hline Maximum & 5000 \\
\hline $95.0 \%$ Cl Mean & 24.51349 to 811.0035 \\
\hline $95.0 \% \mathrm{Cl}$ Sigma & 856.7194 to 1433.034 \\
\hline $\begin{array}{l}\text { Anderson-Darling } \\
\text { Normality Test }\end{array}$ & $\begin{array}{l}\text { A-Squared }=7.252402 ; \mathrm{P} \text { - } \\
\text { value }=0.0000\end{array}$ \\
\hline
\end{tabular}

Figure 15 Box Plot and descriptive statistics for lighting contact off center ( $x 5$ )

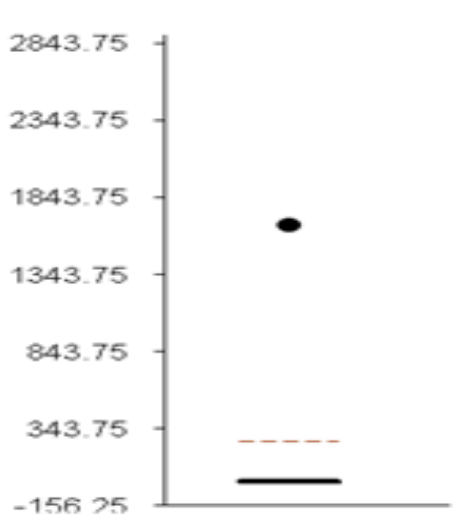

\begin{tabular}{|c|c|}
\hline & $\begin{array}{l}\text { PPM Uneven height of } \\
\text { terminal }(\times 10)\end{array}$ \\
\hline Count & 30 \\
\hline Mean & 262.29 \\
\hline Standard Deviation & 829.35 \\
\hline Range & 3125 \\
\hline Minimum & O \\
\hline 25th Percentile (Q1) & 0 \\
\hline 50th Percentile (Median) & D \\
\hline 75th Percentile (Q3) & O \\
\hline Maximum & 3125 \\
\hline $95.0 \%$ Cl Mean & -47.3999 to 571.9725 \\
\hline $95.0 \%$ Cl Sigma & 660.5037 to 1114.914 \\
\hline $\begin{array}{l}\text { Anderson-Darling } \\
\text { Normality Test }\end{array}$ & $\begin{array}{l}\text { A-squared }=9.449997 ; \mathrm{P}- \\
\text { value }=0.0000\end{array}$ \\
\hline
\end{tabular}

Figure 16 Box Plot and descriptive statistics for uneven height of terminal (x6)

\section{Application of Process Mapping and Six Thinking Hat}

Process mapping is a tool which takes into account and acquires a visualization of current operating processes and particularizing possible potential solutions. So, process mapping is applied in design, inspection, mould design and tools and moulding process for all potential inputs but only application on flashes on contact area of LCS fret base vital input as shown in example Figure 17.

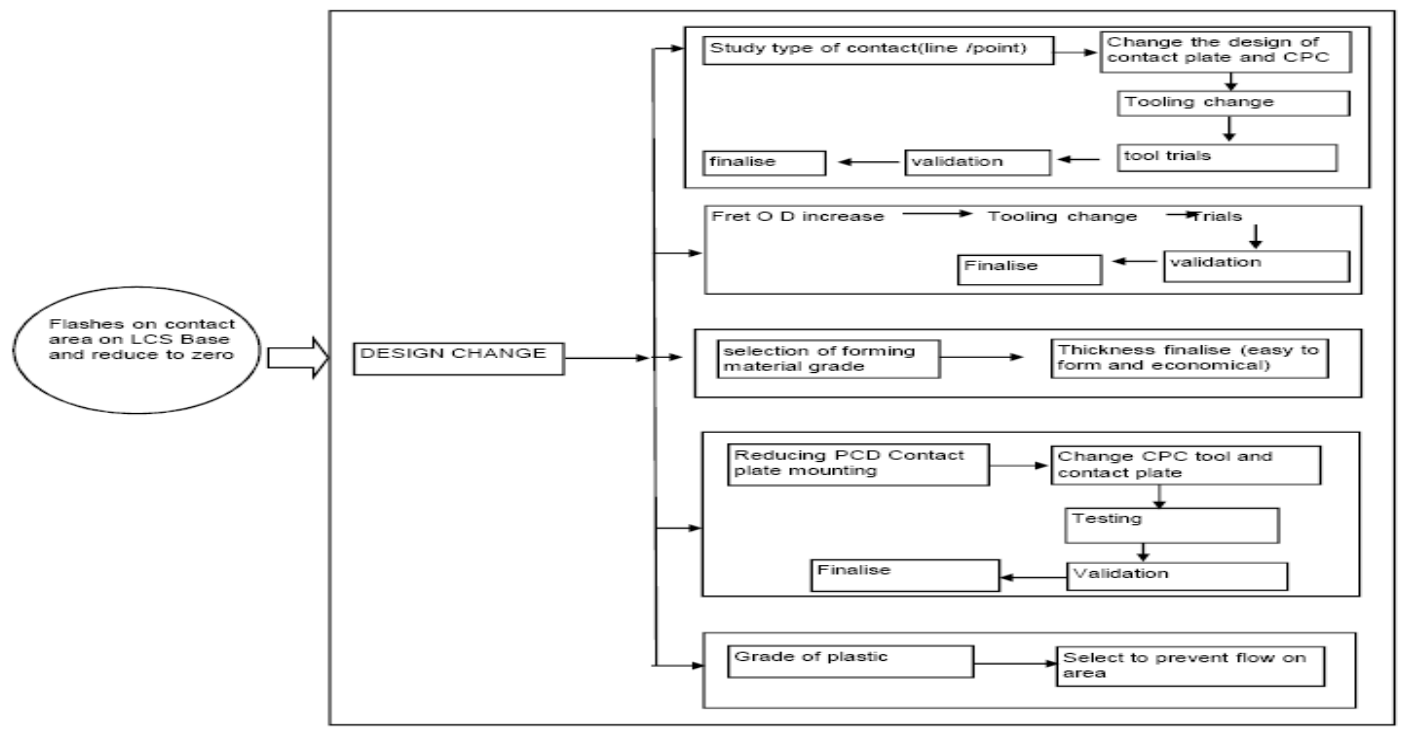

Figure 17 Process mapping for flashes on contact area of LCS fret base (x1) -Design 
Six Thinking Hats' is practical approach which is used to look at determinations from a number of crucial viewpoints. Many successful managerial contemplates from a very rational, positive prospect. Here, 'Six Thinking Hats' technique is applied in design, inspection, mould design and tools as well as moulding process on flashes on contact area of LCS fret base (x1) defective and shown in Table 9 to solve it using this approach. Accordingly it is employed to all critical inputs $\mathrm{x} 2, \mathrm{x} 3, \mathrm{x} 4$ etc. to find necessary solutions and shown in Table $10,11,12$.

Table 9 Six Thinking Hat on Flashes on contact area of LCS fret base (x1) -Design

\begin{tabular}{|c|c|c|}
\hline Green & Black & Yellow \\
\hline $\begin{array}{l}\text { 1)Reducing PCD of contact plate } \\
\text { mounting }\end{array}$ & $\begin{array}{l}\text { 1) There is possibility of no contact } \\
\text { due to contact comes on screw cut } \\
\text { out area. }\end{array}$ & $\begin{array}{l}\text { 1) Sheet thickness change from } 0.8 \\
\text { to } 0.6 \mathrm{~mm}\end{array}$ \\
\hline $\begin{array}{l}\text { 2) Study of line / point contact on } \\
\text { LCS fret }\end{array}$ & $\begin{array}{l}\text { 2) Point contact to be studied form } \\
\text { durability point of view and that } \\
\text { can lead to more problem }\end{array}$ & $\begin{array}{l}\text { 2) Mating parts contact plate } \\
\text { thickness reduces to } 1.5 \mathrm{~mm} \text { to } \\
1.2 \mathrm{~mm} \text { thus making the contact } \\
\text { area free from flash area. }\end{array}$ \\
\hline $\begin{array}{l}\text { 3) Sheet thickness change from } \\
0.8 \text { to } 0.6 \mathrm{~mm}\end{array}$ & $\begin{array}{l}\text { 3)Validation for current carrying } \\
\text { capacity after thickness change. }\end{array}$ & \\
\hline $\begin{array}{l}\text { 4) Alternate material for contact } \\
\text { fret }\end{array}$ & 4) Feasibility and cost to be studied. & \\
\hline $\begin{array}{l}\text { 5)Fret Outer dia. Increased in } \\
\text { turn lever I D and O D increased } \\
\text { (Not practical) }\end{array}$ & $\begin{array}{l}\text { 5) Fret O D Increase might create } \\
\text { problem in mating parts. Major tool } \\
\text { changes and validation , Customer } \\
\text { approval required. Not economical. }\end{array}$ & \\
\hline $\begin{array}{l}\text { 6) Mating parts contact plate } \\
\text { thickness reduces to } 1.5 \mathrm{~mm} \text { to } \\
1.2 \mathrm{~mm} \text { thus making the contact } \\
\text { area free from flash area. }\end{array}$ & & \\
\hline $\begin{array}{l}\text { White } \\
\text { 1) Flashes on area where fret } \\
\text { flatness not ok (Fret bending } \\
\text { area. }\end{array}$ & $\begin{array}{l}\text { Blue } \\
\text { 1)Don't mix up the other X's }\end{array}$ & $\begin{array}{l}\text { Red } \\
\text { 1) More black points, all lenthy } \\
\text { solutions, old design so } \\
\text { complicated that any design change } \\
\text { is causing many changes and hence } \\
\text { not feasible. }\end{array}$ \\
\hline $\begin{array}{l}\text { 2) Daily } 20 \% \text { rejection at } \\
\text { molding assembly. }\end{array}$ & $\begin{array}{l}\text { 2) Don't discuss within yourself, } \\
\text { Discuss within team. }\end{array}$ & \\
\hline $\begin{array}{l}\text { 3) Four numbers daily at final } \\
\text { functional (assembly) }\end{array}$ & $\begin{array}{l}\text { 3) New idea of thickness reduction } \\
\text { from } 1.5 \text { to } 1.2 \text { (contact plate ) to be } \\
\text { added in solution mapping }\end{array}$ & \\
\hline
\end{tabular}

Table 10 Six Thinking Hat on flashes on contact area of LCS fret base (x1)-Inspection

\begin{tabular}{|l|l|l|}
\hline $\begin{array}{l}\text { Green } \\
\text { 1) One inspection gauge to be } \\
\text { made and provide at moulding } \\
\text { operation. }\end{array}$ & $\begin{array}{l}\text { Black } \\
\text { 1) Validation of the gauge for one } \\
\text { day production. } \\
\text { 2) Cycle time of inspection should } \\
\text { be less Feasibility of checking by } \\
\text { operation immediately after molding. }\end{array}$ & $\begin{array}{l}\text { Yellow } \\
\text { 1) Gauge for inspection at molding } \\
\text { operation. }\end{array}$ \\
\hline $\begin{array}{l}\text { White } \\
\begin{array}{l}\text { 1) Ok and not ok components } \\
\text { cannot be fully identified. } \\
\text { Visual Inspection is subjective. }\end{array}\end{array}$ & Blue & $\begin{array}{l}\text { Red } \\
\text { 1) After inspection also defective } \\
\text { being going in assembly line. }\end{array}$ \\
\hline
\end{tabular}


Table 11 Six Thinking Hat on flashes on contact area of LCS fret base (x1)-Mould design \& Tools

\begin{tabular}{|l|l|l|}
\hline $\begin{array}{l}\text { Green } \\
\text { 1) Press Tool design change } \\
\text { from hexagonal to circular }\end{array}$ & $\begin{array}{l}\text { Black } \\
\text { 1) Feasibility of moulding to be } \\
\text { checked. }\end{array}$ & $\begin{array}{l}\text { Yellow } \\
\text { 1) Press Tool design change from } \\
\text { hexagonal to circular }\end{array}$ \\
$\begin{array}{l}\text { 2) Review of mould design } \\
\text { considering the feasibility and } \\
\text { introducing } 0.3 \mathrm{~mm} \text { step in } \\
\text { mould. }\end{array}$ & $\begin{array}{l}\text { 2) Consequent changes in mould } \\
\text { design. }\end{array}$ & $\begin{array}{l}\text { 2) Review of mould design } \\
\text { considering the feasibility. }\end{array}$ \\
\hline $\begin{array}{l}\text { White } \\
\text { 1) Contact area is circular but } \\
\text { fret is hexagonal by design.( } \\
\text { Difference in x \& y is } 0.7 \mathrm{~mm})\end{array}$ & Blue & Red \\
\hline
\end{tabular}

Table 12 Flashes on contact area of LCS fret base (x1)-Moulding process

\begin{tabular}{|c|c|c|}
\hline Green & Black & Yellow \\
\hline $\begin{array}{l}\text { 1) Review of Process } \\
\text { Parameters and start the set up } \\
\text { approval } \\
\text { 2) Setting instructions to be } \\
\text { prepared }\end{array}$ & & $\begin{array}{l}\text { 1) Review of Process Parameters } \\
\text { and start the set up approval } \\
\text { 2) Setting instructions to be } \\
\text { prepared }\end{array}$ \\
\hline & $\begin{array}{l}\text { Blue } \\
\text { 1) Not to be considered design } \\
\text { related issue. You have to think on } \\
\text { moulding process. }\end{array}$ & $\begin{array}{l}\text { Red } \\
\text { 1) No defination of flashes. That's } \\
\text { why rejection material goes to } \\
\text { assembly. }\end{array}$ \\
\hline $\begin{array}{l}\text { 2) } 100 \% \text { Component is having } \\
\text { the plastic material in contact } \\
\text { area. }\end{array}$ & & \\
\hline
\end{tabular}

The following Table 13 shows validation of root causes and necessary actions need to undertake in Improve phase.

Table 13 Validation of root causes:

\begin{tabular}{|c|c|c|c|c|}
\hline \multirow{2}{*}{\multicolumn{2}{|c|}{$\begin{array}{c}\text { Parameter } \\
\text { Y - PPM } \\
\end{array}$}} & \multirow[t]{2}{*}{ Tools used for Validation } & \multicolumn{2}{|c|}{ Status } \\
\hline & & & Accepted & Rejected \\
\hline \multicolumn{5}{|c|}{ Y1-Lighting Stalk Assembly } \\
\hline \multirow[t]{5}{*}{$\begin{array}{c}y 1=\text { Parking } \\
\text { Off }\end{array}$} & $\begin{array}{l}x \mathrm{l}=\text { Flashes on contact area of } \\
\text { LCS Base }\end{array}$ & \multirow[t]{5}{*}{$\begin{array}{c}\text { Descriptive statistics, Box } \\
\text { plot, } \quad \text { Pareto Chart }\end{array}$} & Accepted & $\cdots$ \\
\hline & $\begin{array}{l}\text { Uneven surface of the LCS fret } \\
\text { base }\end{array}$ & & - & Rejected \\
\hline & forming of contact plate & & $\cdots$ & Rejected \\
\hline & CPC pocket width undersize & & - & Rejected \\
\hline & Flash on CPC pocket & & $\cdots$ & Rejected \\
\hline \multirow{3}{*}{$\begin{array}{c}y 2= \\
\text { Printing } \\
\text { Defective }\end{array}$} & $\mathrm{x} 4=$ Scratches on printed symbol & $\begin{array}{c}\text { Descriptive statistics, Box } \\
\text { plot, } \quad \text { Pareto Chart }\end{array}$ & Accepted & - \\
\hline & Printing symbol mismatch & & Accepted & -- \\
\hline & Incomplete printing & & - & Rejected \\
\hline $\begin{array}{l}\mathrm{y} 3=\mathrm{LCS} \\
\text { Snap }\end{array}$ & $\begin{array}{l}\mathrm{x} 2=\text { Excess tightening of screws } \\
\text { and more friction in mating parts }\end{array}$ & $\begin{array}{l}\text { Descriptive statistics, Box } \\
\text { plot, } \quad \text { Pareto Chart }\end{array}$ & Accepted & $\ldots$ \\
\hline
\end{tabular}


Six Sigma practice for process improvement - A case study of medium scale auto ancillary unit

\begin{tabular}{|c|c|c|c|c|}
\hline \multirow[t]{2}{*}{ Defective } & Plunger diameter short mold & $\begin{array}{l}\text { Descriptive statistics, Box } \\
\text { plot, Pareto Chart }\end{array}$ & Accepted & $\cdots$ \\
\hline & Spring box hole diameter & $\begin{array}{l}\text { Descriptive statistics, Box } \\
\text { plot, Pareto Chart }\end{array}$ & Accepted & - \\
\hline \multirow{5}{*}{$\begin{array}{c}\mathrm{y} 4=\mathrm{D} \text { I } \\
\text { Snap } \\
\text { Defective }\end{array}$} & $\begin{array}{l}\mathbf{x} 3=\text { Contact plate dimension } \\
\text { (width and thickness more) }\end{array}$ & \multirow[t]{5}{*}{$\begin{array}{c}\text { Descriptive statistics, Box } \\
\text { plot, } \quad \text { Pareto Chart }\end{array}$} & Accepted & $\cdots$ \\
\hline & Uneven height of terminal & & Accepted & 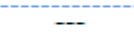 \\
\hline & Burr on contact plate & & - & Rejected \\
\hline & Contact pin diameter less & & $\cdots$ & Rejected \\
\hline & Rotor pocket width and length less & & $\cdots$ & Rejected \\
\hline \multirow[t]{2}{*}{$\begin{array}{l}y 5=\text { Head } \\
\text { Off Blink }\end{array}$} & $x 5=$ Lighting contact off center & $\begin{array}{l}\text { Descriptive statistics, } \text { Box } \\
\text { plot, } \quad \text { Pareto Chart }\end{array}$ & Accepted & $\cdots$ \\
\hline & Cut material (Setting material) & Box plot & $\ldots$ & Rejected \\
\hline \multirow{2}{*}{$\begin{array}{c}y 6=\mathrm{R} i \mathrm{ght} \\
\text { lane } \\
\text { change off }\end{array}$} & $x 6=$ Uneven height of terminal & $\begin{array}{l}\text { Descriptive statistics, Box } \\
\text { plot, } \quad \text { Pareto Chart }\end{array}$ & Accepted & - \\
\hline & Tool Setting (alignment) & Box plot & $\cdots$ & Rejected \\
\hline
\end{tabular}

\section{Improve Phase}

The Improve phases focus on amplifying hypothesis to take away principle causes of variation, examination and standardizing those solutions. As we know, which are critical inputs and affect the outputs then, there is need to run trials to find and confirm the changes in old processes or procedure of these vital inputs and start implementing new processes according to Defects per Millions Opportunities (DPMO) to be reduce which can be called as Design of Experiments (DOE). DOE can be employed as a tool to pin point the influencing factors (x's) which affects on process outputs (y's) and could effectively troubleshoot problem.

\begin{tabular}{|c|c|c|c|}
\hline \multicolumn{2}{|r|}{ Parameter } & \multirow{3}{*}{ Action taken } & \multirow{3}{*}{$\begin{array}{l}\text { Reference } \\
\text { Figures }\end{array}$} \\
\hline \multirow{2}{*}{\multicolumn{2}{|c|}{ Y1-Lighting Stalk Assembly }} & & \\
\hline & & & \\
\hline \multirow{2}{*}{$\begin{array}{l}y 1= \\
\text { Parking Off }\end{array}$} & \multirow[t]{2}{*}{$\begin{array}{l}\mathrm{x} 1=\text { Flashes On Contact } \\
\text { Area of LCS Fret }\end{array}$} & $\begin{array}{l}\text { I) Sheet thickness of fret to be reduced from } \\
0.8 \mathrm{~mm} \text { to } 0.6 \mathrm{~mm}\end{array}$ & \\
\hline & & $\begin{array}{l}\text { II) Moving contact plate thickness to be } \\
\text { reduced from } 1.5 \text { to } 1.0 \mathrm{~mm}\end{array}$ & \\
\hline \multirow[b]{2}{*}{$\begin{array}{l}\text { y } 2=\text { Printing } \\
\text { Defective }\end{array}$} & $\begin{array}{l}\mathrm{x} 4=\text { scratches on printed } \\
\text { symbol }\end{array}$ & $\begin{array}{l}\text { Baking time, curing time and temperature to } \\
\text { be maintained and monitored. }\end{array}$ & Refer Figure 21 \\
\hline & Printing symbol mismatch & $\begin{array}{l}\text { Job mounting fixtures to be corrected from } \\
\text { wooden material to nylon/Aluminum } \\
\text { material. }\end{array}$ & Refer Figure 22 \\
\hline \multirow{4}{*}{$\begin{array}{l}\text { y3 }=\text { LCS } \\
\text { Snap } \\
\text { Defective }\end{array}$} & \multirow{2}{*}{$\begin{array}{l}\text { x } 2=\text { Excess Tightening Of } \\
\text { Screw And More Friction } \\
\text { In Mating Components }\end{array}$} & $\begin{array}{l}\text { I) Applying torque controlled screw driver } \\
\text { during assembly process }\end{array}$ & \multirow{2}{*}{ Refer Figure 23} \\
\hline & & $\begin{array}{l}\text { II) Tool correction of LCS Base mould [ To } \\
\text { avoid parting line on step) }\end{array}$ & \\
\hline & $\begin{array}{l}\text { Plunger Diameter Short } \\
\text { Mould }\end{array}$ & $\begin{array}{l}\text { Process verification and correction at } \\
\text { supplier end. }\end{array}$ & \\
\hline & $\begin{array}{l}\text { Spring Box Hole Diameter } \\
\text { Less }\end{array}$ & Tool correction done & Refer Figure 24 \\
\hline \multirow{3}{*}{$\begin{array}{l}y 4=D I \\
\text { Snap } \\
\text { defective }\end{array}$} & $\begin{array}{l}\text { x3=Contact Plate } \\
\text { Dimension Width And } \\
\text { Thickness More }\end{array}$ & $\begin{array}{l}\text { Press tool:- Press tool design change ( } \\
\text { Contact plate) }\end{array}$ & \\
\hline & \multirow[b]{2}{*}{$\begin{array}{l}\text { Uneven Height Of } \\
\text { Terminal }\end{array}$} & I) Air pressure contro1 & \multirow[b]{2}{*}{ Refer Figure 25} \\
\hline & & II) Tool preventive maintenance frequency & \\
\hline $\begin{array}{l}\text { y5 }=\text { Head } \\
\text { Off Blink }\end{array}$ & $\begin{array}{l}\text { x } 5=\text { Lighting Contact Off } \\
\text { Center }\end{array}$ & Contact plate tool design change & \\
\hline
\end{tabular}

Figure 18 Scratches on printed symbol is corrected by monitoring of baking time and curing time and temperature.

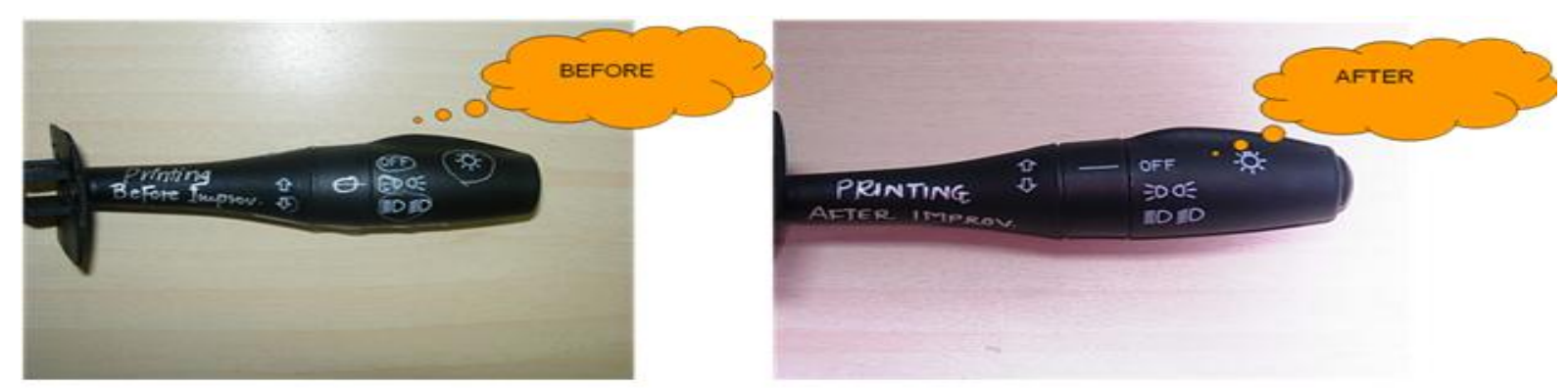


Figure 19 Printing Symbol Mismatch is corrected by fixture for printing changed from wooden material to aluminum material

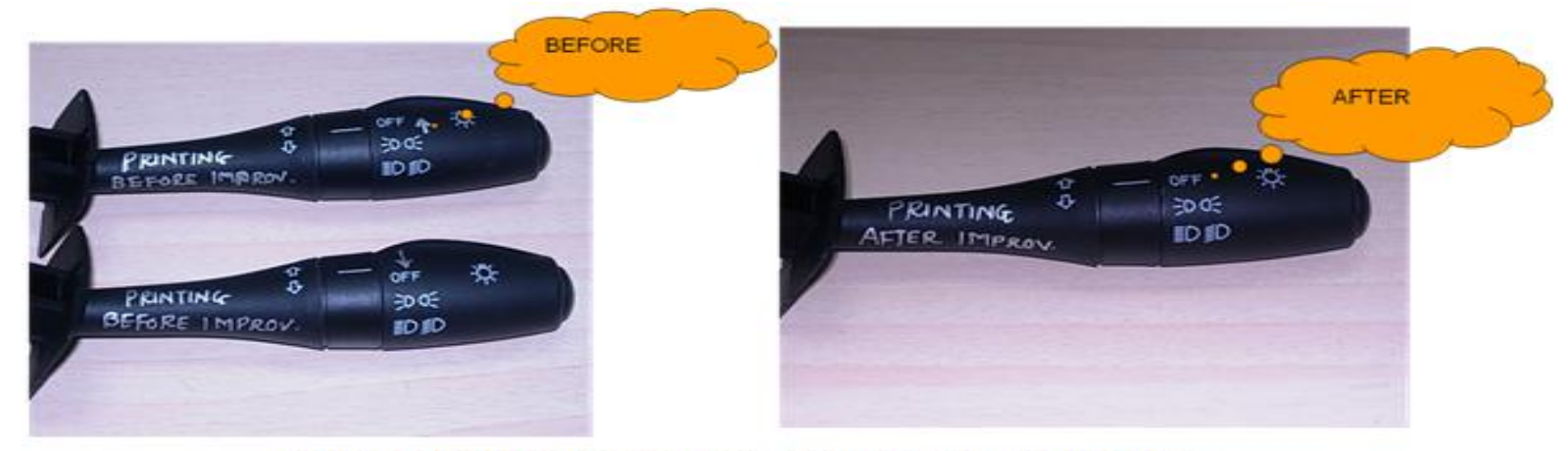

Figure 20 Applying torque controlled screvv driver during assembly process

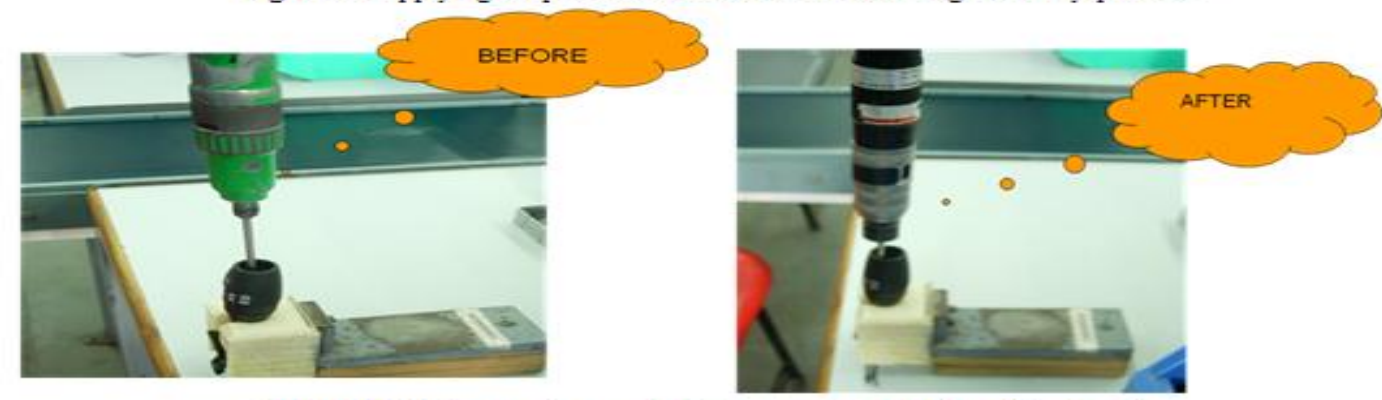

Figure 21 Tool correction made for increase in spring box hole diameter
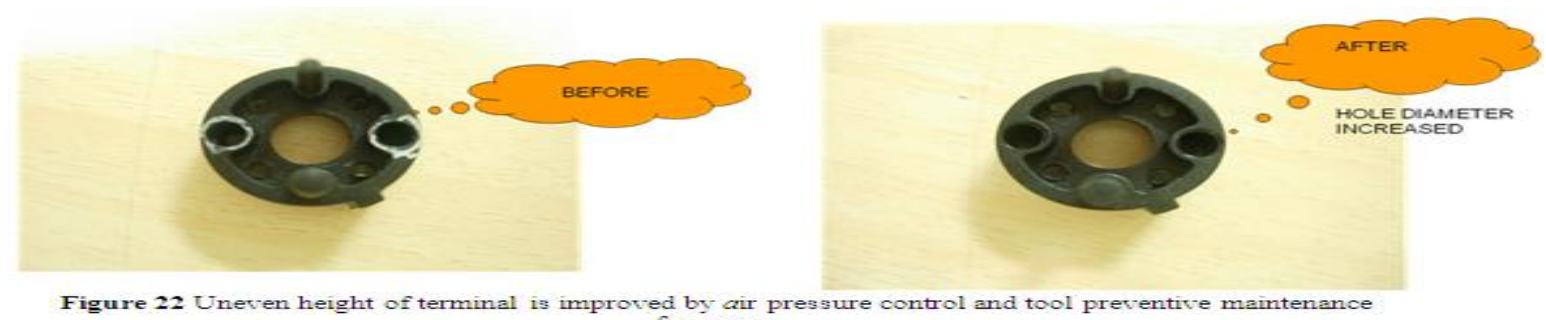

frequency
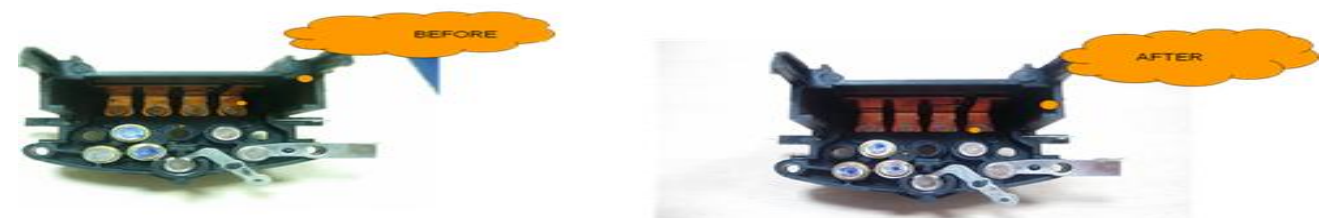

After applying solutions in Improve phase, the following results are obtained for y1, y2, y3, y4 etc. defectives which are shown in following figures.

Figure 23 Pareto for parking off (y1) defectives

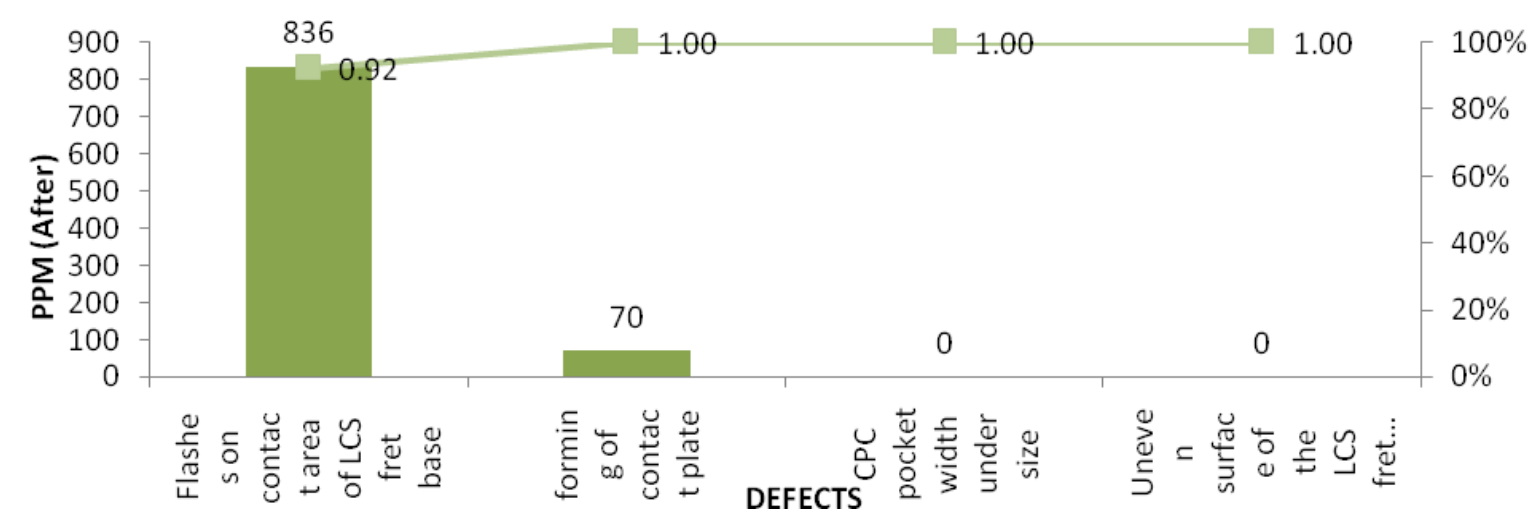

Figure 24 Pareto for LCS Snap Defective (y2) defectives 


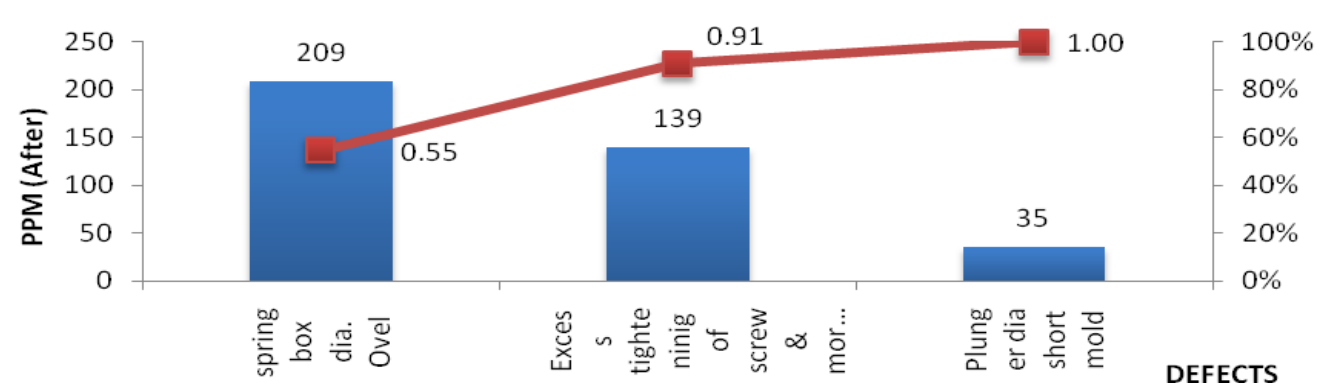

Figure 25 Pareto for D. I. Snap Defective (y3)

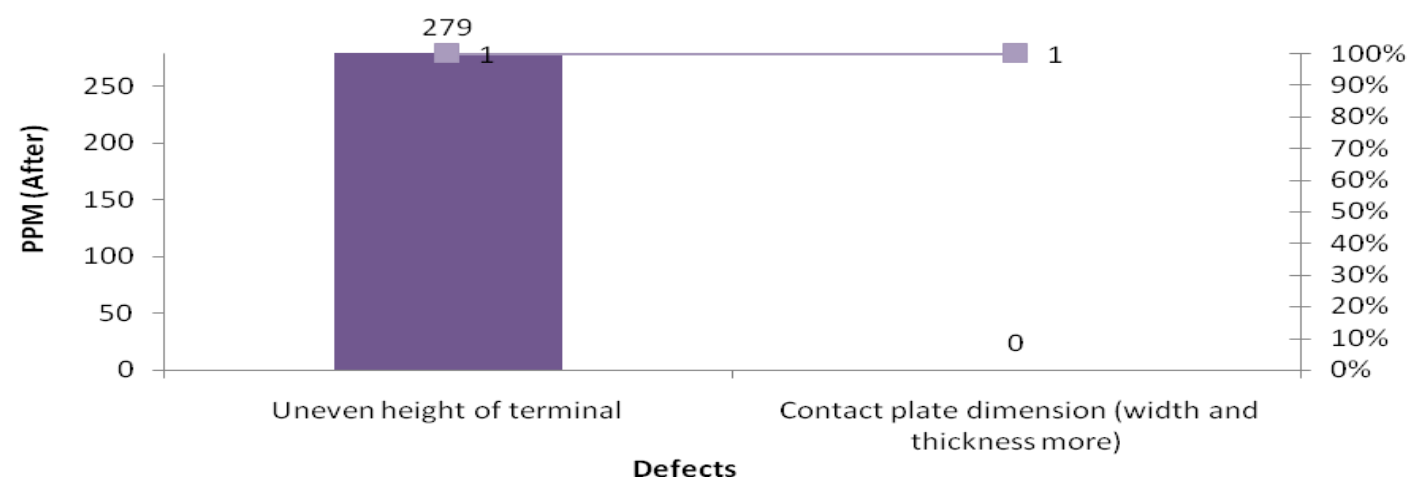

Figure 26 Pareto for printing defective (y4)

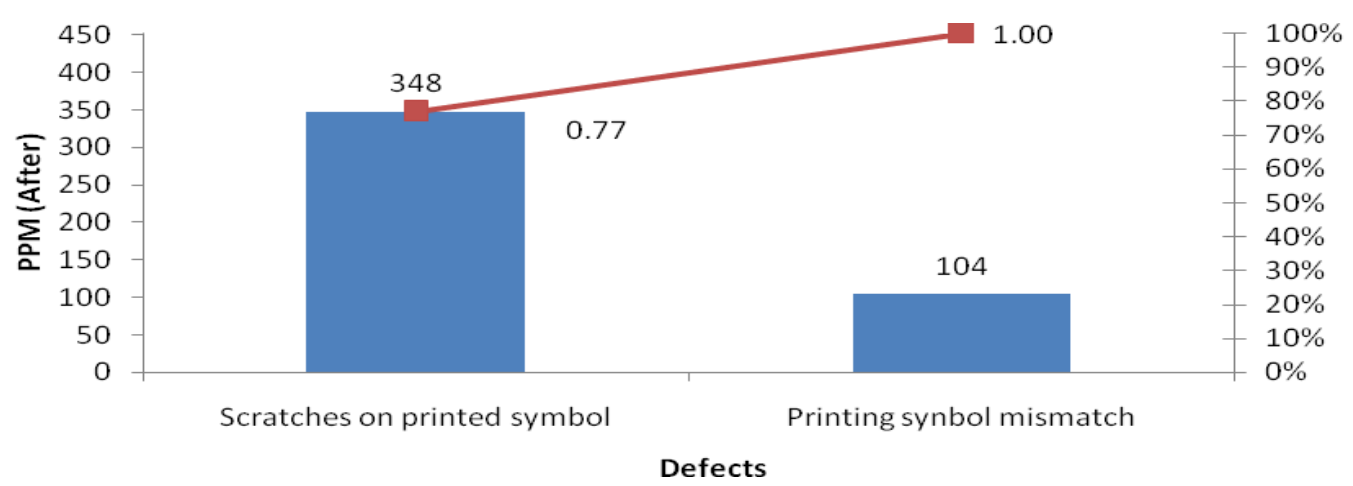

Figure 27 Results obtained after effective implementation for Lighting Stalk Assembly

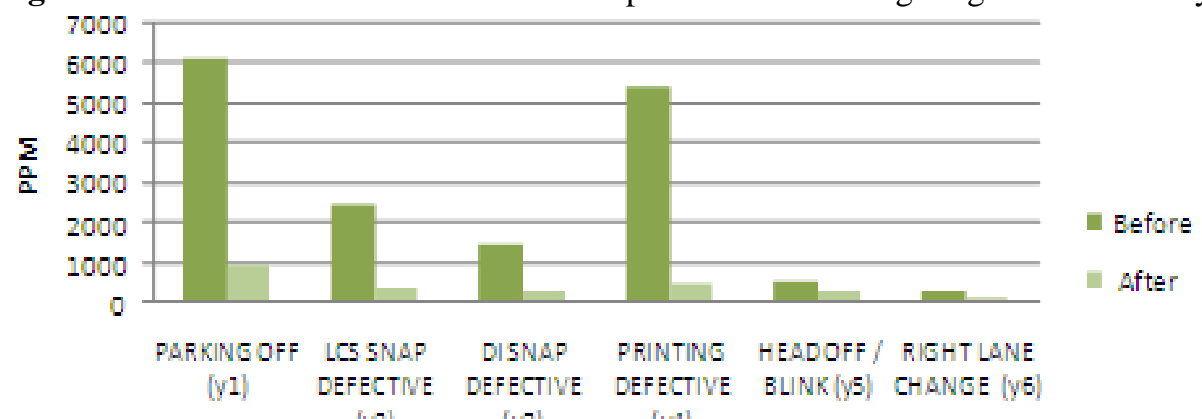

(y2) (y3) (y4)

\section{Control Phase}

Defects (y's)

Once defects have been curtailed then it is necessary to assure that how this improvement is sustained. So, at the end project, the control phase is applied to acclimate gauge measures to asseverate functioning and to correct problems as demanded. This also comprehends to affirm process long-term capability and execute process control exercising control charts to monitor the processes that create the product. The Table 15 shows the sustenance plan implemented after accomplishment of this project. 


\begin{tabular}{|l|c|c|c|}
\hline \multicolumn{1}{|c}{ Parameter } & Cable 15 Sustenance Plan & \multicolumn{2}{c|}{ Capability Index } \\
\cline { 3 - 4 } & & Before & - \\
\hline $\begin{array}{l}\text { No flashes on contact area of } \\
\text { LCS }\end{array}$ & P Chart & - & - \\
\hline LCS plunger Dia. short mold & P Chart & - & 1.49 \\
\hline D. I. Contact Plate Thickness & X Bar - R chart & Not Capable & - \\
\hline $\begin{array}{l}\text { Air pressure control on } \\
\text { riveting machine }\end{array}$ & Introduction of cut off valve & - & - \\
\hline $\begin{array}{l}\text { Baking time, Curing time and } \\
\text { temp. in printing }\end{array}$ & Temp. indicator vith siren, \\
\hline $\begin{array}{l}\text { Lighting contact dimple } \\
\text { position }\end{array}$ & Buzzer, MII & - & 1.32 \\
\hline No flash on rotor pocket & X Bar - R chart & 0.703 & - \\
\hline Spring Dia. Of wiper side & X Bar - R chart & - & 0.92 \\
\hline
\end{tabular}

\section{CONCLUSION}

This Six Sigma quality management practice exhibits to improve stratum as well elevate internal and external customers' atonement; redesign manufacturing processes in perspective of curtailing or eliminating defects; creating culture of perpetual improvement, but it needs right focus and commitments. To initiate Six Sigma specifically in SMEs, the top management should locate enthusiastic personnel's as team members from their enterprises and get trained at least on Green Belt through external agencies or customer organisation if they acute to support. Then enterprises can think to apply 'Internal Training Methodology' (ITM) for education and training on SS for hierarchical downlink through these trained personnel, since SMEs can't be ready to invest in heavy consultancy cost for massive training. After accomplishing one project, enterprise can deploy new projects for different CTQs', render savings, then upgrade staff for higher belt levels and then elevate speed of implementation. The Six Sigma results can be further improved by employing advanced tools viz. Design of Experiment (DOE) as well software tool viz. Minitab.

\section{ACKNOWLEDGEMENT}

We will quote special thanks to Dr. R. S Dalu, Head (Mechanical Engg.), Government College of Engineering, Amravati, Mr. Praful Kalankar, Sr. Manager (Manufacturing \& Quality) and Hon. Management of the enterprise for permission to perform this case study as well for their valuable guidance and cooperation at the time of project implementation.

\section{References}

[1] (2008), "Defining the Role of the Government in the Transnationalisation Efforts of the Indian SMEs in the Auto Components Sector", Department of Scientific and Industrial Research (DSIR), Ministry of Science and Technology, New Delhi, Published by: IDC (India) Limited CYBER HOUSE, B-35, Sector 32-Institutional,Gurgaon Last Visited 15 March 2011 , www.dsir.gov.in/reports/ittp_sme/AutoCompReport.pdf

[2] (2006), "A report by KPMG for IBEF, Auto Components", Indian Brand Equity Foundation, http://www.ibef.org/industry/autocomponents.aspx, retrieved on June 2010

[3] Bell, R. (2011), "A Comparison of Four Quality Improvement Approaches", Article Directory, http://articleco.com/2011/03/21/acomparison-of-four-quality-improvement-approaches/ retrieved on Jan 2012

[4] Pfeifer, T., Reissiger, W. and Canales, C. (2004), "Integrating Six Sigma with quality management systems", The TQM Magazine, Vol. 16, No. 4, pp $241-249$.

[5] Does, R., Heuvel, E., Mast, J. and Bisgard, S. (2002), "Comparing non-manufacturing with traditional applications of Six Sigma", Quality Engineering, Vol. 15, No. 1, pp. 177 - 182.

[6] Berghe W. (1997), "Application of ISO 9000 standards to education and training”, Interpretation and Guidelines in a European Perspective", Published by: CEDEFOP European centre for Development of Vocational Training, First Edition, ISBN $92-827$ www.oitcinterfor.org/public/english/region/ampro/cinterfor/temas/calidad/doc/iso.pdf

[7] Patel, D. (2004), "Initiation and implementation of Six Sigma in a small organization", Wichita State University, Department of Industrial and Manufacturing Engineering.

[8] Gnibus, R. and Krull, R. (2003), "Small Companies See the Money", Quality, Vol. 42, No. 8. pp. 48

[9] Pandey, A. (2007), "Strategically focused training in Six Sigma way: a case study", Journal of Europeans Industrial Training, Vol. 31, No. 2, pp. 145-162

[10] Breyfogle III, F.W., Cupello, J.M. and Meadows, B. (2001), "Managing Six Sigma", John Wiley and Sons, New York

[11] Thomas, A., Barton, R. and Chuke-Okafor, C. (2009), "Applying Lean Six Sigma in a Small Engineering Company - A Model for Change”, Journal of Manufacturing Technology Management, Vol. 20, No. 1, pp. 113-129

[12] Gordon, T. (1995), "The underlying fallacies of lean and mean, The Ironbridge group, USA", BPICS Control, August, pp. 4-11

[13] Gnibus, R. and Krull, R. (2003), "Small Companies See the Money", Quality, Vol. 42, No. 8. pp. 48

[14] Desai, D.A. (2008), "Improving productivity and profitability through Six Sigma: experience of a small-scale jobbing industry", International Journal of Productivity and Quality Management, Vol. 3, No.3, pp. 290 - 310.

[15] Desai, D. A. (2006), "Improving customer delivery commitments the Six Sigma way: case study of an Indian small scale industry", International Journal of Six Sigma and Competitive Advantage, Vol. 2, No. 1, 23-47.

[16] Kumi, S. and Morrow, J. (2006), "Improving self service the Six Sigma way", Newcastle University Library Program: Electronic Library and Information Systems, Vol. 40, No. 2, pp.123-136.

[17] Pande, P., Neuman, R., and Cavanagg, R. (2000), "The Six Sigma way: how GE, Motorola, and other top companies are honing their performance", Publisher: McGraw-Hill; 1 edition (April 27, 2000), New York., Hardcover: 448 pages; ISBN: 0071358064 